\title{
Constitutional Courts and the Rule of Law in the New EU Member States
}

\author{
Angela Di Gregorio \\ University of Milano, Italy \\ Angela.digregorio@unimi.it
}

\begin{abstract}
This paper analyses the use of the rule of law principle in the jurisprudence of the constitutional courts of the new member states of the European Union. The purpose is to discover whether past or recent decisions could clarify the use of the principle in these countries. An example is the legalistic concept of the rule of law as expressed by the Hungarian and Polish constitutional courts when they examined the constitutionality of the lustration laws. On the other hand, some constitutional courts (such as the Czech one) have used a wider and more sophisticated application of the rule of law. Considering the severe rule of law crisis which has been taking place in Hungary and Poland in recent years, this recognition is particularly important in order to avoid cumulative judgments that could devalue the former communist countries in general, trivializing the harsh path of democratic conditionality with its strengths and weaknesses.
\end{abstract}

\section{Key words}

constitutional courts - new EU member states - rule of law - sources of law - EU conditionality

\section{Introduction}

In recent years, the rule of law narrative has been predominant in the constitutional law literature. Although a discussion of the theoretical side of the rule of law principle would be very useful, given that the discourse on the rule of law is both used and abused, ${ }^{1}$ the goal of this paper is to look at the jurisprudential safeguards or interpretations of the principle focusing on the new EU members (countries that joined the EU in 2004, 2007 and 2013) to especially highlight their value and cultural context. In fact, although there is a general awareness of a deterioration in the state of health of the rule of law in Hungary and Poland, ${ }^{2}$ it should be underlined that in other countries, because of the support of the constitutional courts, this principle is quite firmly protected.

The countries of Central and Eastern Europe have experienced in their history different transitions between different political systems, which also included complex processes of state building and restructuring, which explains their high sensitivity to issues of sovereignty and constitutional identity. Some of them enjoyed experiences of parliamentarianism and rule of law within the Austro-Hungarian empire and then, in the period between the two World Wars, they lived an important season of constitutionalism. ${ }^{3}$ At the

\footnotetext{
${ }^{1}$ This topic is highly complex and is connected with that of the democratic nature of the state and of the EU. See Gianluigi Palombella, "Beyond Legality - Before Democracy. Rule of law Caveats in the EU Two-Level System", in Carlos Closa and Dimitry Kochenov (eds.), Reinforcing Rule of Law Oversight in the European Union (CUP, Cambridge, 2016), 36. See also, Jean-Philippe Derosier, "The uselessness of an allo-synthetic concept: 'Rule of Law' and 'État de Droit' from a French public law perspective”, 57 (1) Hungarian Journal of Legal Studies (2016), 1-9 and Armin Von Bogdandy, "Ways to Frame the European Rule of Law: Rechtsgemeinschaft, Trust, Revolution, and Kantian Peace", 14 (4) European Constitutional Law Review (2018), 675-699.

${ }^{2}$ For the main solutions envisaged, see Closa and Kochenov, 2016, op.cit. note 1. See also Angela Di Gregorio, "Lo stato di salute della rule of law in Europa: c'è un regresso generalizzato nei nuovi Stati membri dell'Unione?”, 4 DPCE on-line (2016), 173-202, available at <www.dpceonline.it/index.php/dpceonline/article/view/72>.

3 Boris Mirkine-Guetzévitch, Les Constitutions de l'Europe Nouvelle (Delagrave, Paris, 1930); Id. Les nouvelles tendances du droit constitutionnel (Marcel Giard, Paris, 1931); Amedeo Giannini, Le Costituzioni degli Stati
} 
end of the communist system of government, a complex transition to democracy took place on different levels, including the constitutional level.

The first decade after 1989 was characterized by the learning of democracy. Towards the end of this period, the construction of a new society with a democratic political system took precedence over the destruction of the old system, alongside the emergence of a new pluralistic political culture. The countries in question entered the Council of Europe and adopted new constitutions characterized by the influence of not only Western models but also of national traditions. The following period was characterized by the intensification of preparations to enter the European Union, which also included a series of constitutional amendments; for example, special provisions were introduced to allow limitation of sovereignty, and the relationship between sources of domestic and international law was clarified. Considering the context, these countries represent an interesting case of innovation in the field of comparative law, because of aspects such as the emphasis on the rule of law in post-communist constitutions, ${ }^{4}$ the influence of German doctrine and case law, ${ }^{5}$ the rich academic debate on the rule of law and other fundamental principles, and extensive constitutional jurisprudence on these principles. ${ }^{6}$ Notwithstanding the influence of Western European models, many cultural differences exist among the 'old' and the 'new' EU member states, because of a delayed and autochthonous path of constitutionalism in the latter.

The attitude of constitutional courts to the rule of law is an old issue, ${ }^{7}$ but it is periodically explored anew, especially in times of transition or crisis. ${ }^{8}$ The contribution of the constitutional courts of the new EU members is particularly important for two main reasons. First, these courts give an accurate definition of a principle that is vague and rarely defined in constitutions. ${ }^{9}$ Second, in countries that have experienced authoritarian or communist rule, the constitutional courts contribute to the creation of distance from the previous legalistic, positivist and ideological legal interpretations. As has already been noted, in the new

dell'Europa orientale (Istituto per l'Europa orientale, Roma, 1929); Georges Burdeau, Le régime parlementaire dans les constitutions européennes d'après-guerre (Éditions internationales, Paris, 1932).

${ }^{4}$ Jon Elster, "Constitutionalism in Eastern Europe: An Introduction”, 58 (2) University of Chicago Law Review (1991); Cass R. Sunstein, Something Old, Something New, 1 (1) EECR (1992).

5 Allan F. Tatham, Central European Constitutional Courts in the Face of EU Membership. The Influence of the German Model in Hungary and Poland (Martinus Nijhoff Publishers, Leiden, 2013); Michal Bobek, "Conclusions: Of Form and Substance in Central European Judicial Transitions", in Michal Bobek (ed.), Central European Judges Under the European Influence: The Transformative Power of the EU Revisited (Hart Publishing, Oxford, 2015).

${ }^{6}$ See, e.g., Jadranka Sovdat (ed.), Conference proceedings / International Conference Constitutional Court of the Republic of Slovenia - 25 Years, Bled, Slovenia, June 2016 (Constitutional Court of the Republic of Slovenia, 2016), available at $<$ www.us-rs.si/media/zbornik.25.let.pdf $>$. See also the reports published in Richard Albert, David Landau, Pietro Faraguna, and Simon Drugda (eds.), 2016 Global Review of Constitutional Law, available at $<$ http://www.bc.edu/content/dam/files/centers/clough/constitutional-law/ReviewofConLaw-final.pdf $>$.

${ }^{7}$ See, e.g., the conference organised in 1994 by the Council of Europe on "The Role of the Constitutional Courts in the Consolidation of the Rule of Law", Bucharest, 8-10 June 1994. Proceedings available at $<$ www.venice.coe.int/webforms/documents/default.aspx?pdffile=CDL-STD(1994)010-e $>$.

${ }^{8}$ This is evidenced by the subject of the Vilnius 4th Congress of Constitutional Justice Conference, which was "The Rule of Law and Constitutional Justice in the Modern World". The focus of the conference was quite explicit in this regard, with particular reference to the countries of Central and Eastern Europe. National reports are available at <www.wccj2017.lt/data/public/uploads/2016/09/questionnaire-wccj-ga2016005-e.pdf>. The topic of the Batumi XVIIth Congress of the European Constitutional Courts ("Role of the Constitutional Courts in Upholding and Applying the Constitutional Principles") was not very different; reports are available at $<$ www.confeuconstco.org $>$.

${ }^{9}$ The rule of law is a collection of principles rather than a single principle, as evidenced by the literature and by the Rule of Law Check-list of the Venice Commission, available at <www.venice.coe.int/webforms/documents/default.aspx?pdffile=CDL$\mathrm{AD}(2016) 007-\mathrm{e}>$. See Albert V. Dicey, Introduction to the Study of the Law of the Constitution (Macmillan, London, 1885 and subsequent editions); Brian Z. Tamanaha, On the Rule of Law: History, Politics, Theory (CUP, Cambridge, 2004); Pietro Costa and Danilo Zolo (eds.), Rule of Law: History, Theory and Criticism (Springer, Dordrecht, 2007); Mortimer Sellers and Tadeusz Tomaszewski (eds.), The Rule of Law in Comparative Perspective (Springer, Dordrecht, 2010); Martin Krygier, "Rule of Law", in Michel Rosenfeld and Andras Sajo (eds.), The Oxford Handbook of Comparative Constitutional Law (OUPress, Oxford, 2015), 233-249. 
constitutions the principle of the rule of law is explicitly emphasized, ${ }^{10}$ and it is considered, as we can deduce from an analysis of the constitutional jurisprudence, to be a directly applicable principle capable of invalidating acts that are inconsistent with it. ${ }^{11}$

The topic is very wide, which means that an assessment must mainly be made on the basis of some aspects or phases of the case law relating to the rule of law:

a) the long phase of transition to democracy and, in particular, issues of transitional justice;

b) the rule of law as it appears in the relationship between domestic and European sources of law, ${ }^{12}$ or the rule of law as (a legitimation or) a limit on the penetration of European law; ${ }^{13}$

c) the division of state powers, and in particular, the independence of the judiciary.

Especially the first two are particularly important issues to clarify the relevance of rule-of-law discourse for the development and consolidation of a new democratic legal system. Both the genesis of the new democratic order with the attitude to be taken towards the previous order from one side and, on the other, the limitation of state sovereignty in order to be integrated into the European design, have challenged the principle of the rule of law. In both cases we are talking about issues that are still current: if the path of European integration is a work in progress and clashes between national and EU legal systems occur periodically, the relationship with the past also proves to be still painful.

We will not discuss in detail the different sub-principles of the rule of law in constitutional jurisprudence. ${ }^{14}$ Such an approach could be useful and understandable for the old democracies, while for the new ones more careful reflection is needed on aspects linked to the transformation of the legal culture. ${ }^{15}$ Thirty years after the transition to democracy for the former communist countries the question of values and their solidity is still relevant, if we consider that the questioning of certain values threatens to undermine the very foundations of European integration.

\section{Transitional Justice and the Rule of Law. A Formal or Material Conception of the Rule of Law}

At the time of the collapse of the communist regime, almost all the countries of Central and Eastern Europe adopted a series of measures aimed at reckoning with the past, focusing especially on politicaladministrative purges. In particular, they needed a new ruling class not compromised with the past and demonstrating a 'democratic loyalty' as in the German experience of wehrhafte or streitbare Demokratie. ${ }^{16}$ They introduced so-called 'lustration', namely the removal from high public positions of former members of the communist party and/or — more frequently — of former officials and collaborators of the secret services,

${ }^{10}$ Unlike the older European constitutions, which do not emphasize the principle even though some of them (the German, Spanish, Finnish, Portuguese, Swedish and Swiss constitutions) make provision for it, as does the US Constitution.

${ }^{11}$ In several cases, the acts or provisions that were challenged were repealed because they were inconsistent either solely with the principle of the rule of law or most importantly with this principle. This happened, for example, in Slovakia, Romania, Bulgaria, Lithuania, and Poland.

12 See the Venice Commission Rule of Law Check-list of 2016 (op. cit note 9), especially point 48. See also Dainius Žalimas, "The openness of the constitution to international law as an element of the principle of the rule of law", in Sovdat, op.cit. note $6,141 \mathrm{ff}$.

${ }^{13}$ Tatjana Evas, Judicial Application of European Union Law in Post-Communist Countries. The Cases of Estonia and Latvia (Ashgate publishing, Farnham, 2012); Bobek (ed.), op.cit. note 5.

${ }^{14}$ Among the components of the rule of law that are most often highlighted by the constitutional courts of the countries examined are: legal certainty (by far the most used principle), legality, confidence in law and legitimate expectation, predictability of legal acts, non-arbitrariness, and non-retroactivity. From a substantive point of view, the most emphasised are the purposes of the use of power and substantive justice. A detailed overview of these aspects is included in the questionnaires that the constitutional courts prepared for the conferences in Batumi and Vilnius mentioned above: see websites, op.cit. note 8.

15 Adam Czarnota, Martin Krygier, Wojciech Sadurski (eds.), Rethinking the rule of law after communism (CEU Press, Budapest, 2005).

${ }^{16}$ On this subject, see Angela Di Gregorio, Epurazioni e protezione della democrazia. Esperienze e modelli di "giustizia post-autoritaria" (FrancoAngeli, Milano, 2012). 
who were perceived as particularly hateful for their covert surveillance activity during the communist regime. The reasons for adopting lustration legislation and the results of its application vary from country to country. ${ }^{17}$ Another important transitional justice measure has been the reopening of the statute of limitations.

Constitutional courts have dealt with various aspects of measures to come to terms with the past, and have influenced the political agenda on the subject - sanctioning, correcting, or endorsing the choices of the legislator. Many of them used the rule of law parameter to adjudicate these measures, especially but not exclusively at the beginning of their activity. Particular examples of this are seen in decisions concerning reopening or removal of statutes of limitation for offences committed during the communist regime (or in wartime, in the case of Croatia) or concerning lustration ${ }^{18}$ and restitution of property.

Here we can distinguish three different attitudes. At one end of the spectrum, some courts have expressed a rigidly material, content- and value-oriented interpretation of the rule of law. These are the Czechoslovakian and the Czech Constitutional Courts, ${ }^{19}$ which bring to mind the similar natural law orientation of the German courts in relation to the crimes of the Nazi and communist past. At the other extreme, there are constitutional courts that have adopted a highly legalistic attitude, characterized by a formalistic view of the rule of law (the Hungarian and Polish Constitutional Courts). The Croatian Constitutional Court is in the middle (if the 2015 Hypo case is taken into account), as too are the Romanian and Bulgarian Constitutional Courts, which have criticised retrospective measures by using a mixture of a formal and a material conception of the rule of law.

\subsection{A Strictly Substantive Interpretation of the Rule of Law: The Czech Case}

The Czech Constitutional Court is certainly the one that has displayed the most consistent interpretation of the rule of law. There are cultural reasons explaining this position, such as the traditions of the first Czechoslovak Republic, the influence of German jurisprudence, and the strong desire of the Court to distance itself from the the way the law was interpreted during the communist period. The Court not only expressed a material view of the rule of law, but also did not deny the relevance of the formal rule of law and, at the same time, disagreed with a formalistic interpretation of the law that could lead to sophisticated justifications of an obvious injustice (III. ÚS 127/96). The coherence of this Court has never failed, so much so that the first decision adopted in plenary session is still considered to be a landmark of constitutional law and is periodically recalled. From this milestone, the following case law and the current interpretation of the rule of law - and of other fundamental principles - derive, uniting the rule of law with democracy as foreseen in Article 1, paragraph 1 of the constitution ("democratic state governed by the rule of law"). ${ }^{20}$

This is the judgment of 21 December 1993 (Pl. ÚS 19/93) on verification of the "Act on the lawlessness of the communist regime" which included criminal law measures, namely recalculation of the statute of limitations for crimes committed between 1948 and 1989 that were not pursued for political reasons. The Court considered the law to be consistent with the Constitution, criticising constitutional neutrality over values, which would be associated with positivism and a "legalistic conception of political legitimacy". ${ }^{21}$

\footnotetext{
${ }^{17}$ We can distinguish different models, more or less strict. See Wojciech Sadurski, 'Decommunisation', 'Lustration', and Constitutional Continuity: Dilemmas of Transitional Justice in Central Europe”, EUI Working Papers, Law, No.2003/15; Kieran Williams, Aleks Szczerbiak, Brigid Fowler, "Explaining Lustration in Eastern Europe: 'A postcommunist politics approach", 12 Democratization (2005); Roman David, "From Prague to Baghdad: Lustration Systems and Their Political Effects", 41 Government \& Opposition (2006).

${ }^{18}$ In most cases, they have invalidated all or part of the lustration legislation. Only the Czechoslovak and Czech constitutional courts have endorsed the legislatures' choices without major conditions.

${ }^{19}$ The Constitutional Court of Slovakia also embraces a material conception of the rule of law, not in transitional justice issues but in dealing with the autonomy of the judiciary.

${ }^{20}$ On the possibility of conflict between these two values given their different vocation, see Pavel Rychetský, "The role of the Constitutional Court in strengthening the rule of law in the Czech Republic", in Sovdat, op.cit. note 6, 157.

${ }^{21}$ The decision is placed in continuity with the judgment of the Constitutional Court of the Czech and Slovak Federal Republic (Pl. ÚS 1/92) on the Czechoslovak lustration act, which explained why the communist legal order could not be
} 
The Court dwelt on a complex disquisition on the rule of law principle, refusing to accept a formal definition of legality or to merge legality with legitimacy, the latter notion being contingent on the democratic character of the state ("a political regime is legitimate if accepted as a whole by the majority of citizens"); the fact that some laws adopted before 1990 continued to be in force did not mean that the old regime was given legitimacy: "Although there is continuity of 'old laws' there is discontinuity of values with the values of the old regime". According to the Court, the suspension of the statute of limitations was legitimate, as during the communist period the law was only a tool of the regime. In other words, the act that was being examined deemed that the statute of limitations was fictitious in the communist period, and carried out an ex post suspension of the limitation period. The Court's discourse in this decision goes beyond the case under consideration, giving a broad lecture on constitutional history - with reference to Central Europe between the two World Wars - and on constitutional law, as well as serving as an almost militant ideological break with the past. The Court intended to differentiate its material discussion of the rule of law from the formal and legalistic one that had allowed the emergence of totalitarianism. ${ }^{22}$

With regard to the subsequent case law on transitional justice, there are many cases that reiterate the same conception of values and regime discontinuity and recall the first plenary judgment of 1993 . We may mention, among the best known of these: judgment Pl. ÚS 9/01 of 5 December 2001, in which the Court ruled on the extension of the lustration law (the focus was on the loyalty of public officials to the values of democracy); ${ }^{23}$ judgment I. ÚS 420/09 of 3 June 2009, in which the Court mentioned, in order to distance itself from it, the positivist position of Weyr, a well-known constitutionalist of the first Republic and a member of the Kelsen school of the pure theory of law; and judgment I. ÚS 517/10 of 15 November 2010, in which the Court again recognised the importance of clarifying the past of public officials. ${ }^{24}$

Two cases from 2016 are also worth mentioning. The first was decided by judgment I. ÚS 3964/14 of 13 June 2016, in which the Court censured the formalistic behaviour of the ordinary courts, which had refused to accept the applicant's request for compensation for the property lost by her grandmother following the assignment of Subcarpathian Ruthenia to the USSR. The refusal had been based on the application of a 1959 decree. In this case, the Court reiterated the necessity for the discontinuity of values and outlined the duty of the courts to reflect on the modern concept of the material rule of law. The Court underlined the necessity of interpreting restitution norms in light of their sense and their purpose of alleviating the wrongs caused by the previous illiberal regimes. ${ }^{25}$ In decision I. ÚS 3943/14 of 2 August 2016, the Court dealt with the restitution of confiscated property to the family of a Jewish citizen who had been exterminated in the concentration camps (the property had been requisitioned first by the Third Reich and then by the communists as German property). In this case, the Court even mentioned the Radbruch formula, testifying to its adherence to the

considered 'legitimate' even though it was 'legal'. The basis of the reasoning of both the Czechoslovak and the Czech Constitutional Courts is the so-called 'theory of values' which, being different in the communist and democratic legal order, fill the same legal institutions (such as the principles of legal certainty or equality) with different and opposing content. Therefore, the contested act, which implied new values, should not be interpreted as a measure of discrimination against certain categories of persons, as it merely set out, for the future, certain further requirements for the exercise of functions considered to be decisive, or for access to those functions.

${ }^{22}$ As the Court pointed out, Klement Gottwald succeeded, in the coup of February 1948, in legitimizing the seizure of power through formal respect for constitutional procedures.

${ }^{23}$ For a general comment on the case law on lustration, see David Kosař, "Lustration and Lapse of Time: "Dealing with the Past" in the Czech Republic", 4 European Constitutional Law Review (2008), 460.

${ }^{24}$ In this case, it was necessary to check whether a judge had been affiliated with the communist party of the former Czechoslovakia as a prerequisite for possibly asking for and deciding on his recusal. The Court considered that such membership could affect the judge's decision-making process, because the system of values of the members of the communist party was different from the values of a modern democratic state based on the rule of law (because they included extreme formalism and legalism, a simple cognitive model of legal interpretation, and a simplistic conception of the sources of law).

${ }^{25}$ Before this, in 2015, the Court had dealt with a similar case in judgment I. ÚS 1713/13 of 23 February 2015, which concerned procedural issues for the exercise of a claim for compensation for property left in Subcarpathian Ruthenia. According to the Constitutional Court, the formalistic tendency of the courts would prevent appeals against administrative acts, to the detriment of the applicant. 
material vision of the rule of law in which in certain circumstances substantive justice prevails over legal certainty. ${ }^{26}$

\subsection{A Formalistic View of Legal Certainty by the Hungarian Court (followed by the Polish CT), with Recent Developments}

As far as Hungary is concerned, it is explicit in both the old amended Constitution (preamble and Article 2) and the new Fundamental Law (Article B.1) that Hungary is a democratic state based on the rule of law. In both constitutional phases, the Constitutional Court interpreted the principle, but the interpretations are partially different because the 2011 Fundamental Law adopts an attitude that is based on a discontinuity of values.

In the first period after the transition to democracy, the Constitutional Court opted for a formalistic view of the rule of law. ${ }^{27}$ The most important in this regard is decision no. 11/1992 of 5 March 1992, in which the Court examined the reopening of the limitation period under the Act of 4 November 1991. The particular intention of the challenged Act was to punish those who had been involved in the suppression of the 1956 revolution. President Göncz refused to sign the law, sending it to the Constitutional Court, which declared it unconstitutional particularly because of its unacceptable vagueness: the expression "based on political reasons" 28 was not sufficiently clearly defined to cover a period of more than 40 years.

The Court based its decision on a particular conception of the rule of law: in a constitutional state "not only the legal provisions and the actions of the state organs must be strictly in conformity with the Constitution, but the values of the Constitution and its conceptual culture must penetrate the entire society". Since the transition to democracy had taken place in a legal way, there should be no distinction between acts approved before and after the new Constitution. ${ }^{29}$ On this basis, the Court applied the principle of legal certainty, a fundamental requirement of the rule of law, by holding that the contested act was lacking in that regard. ${ }^{30}$ According to the Court, the Constitution did not and could not confer a right to substantive justice: "reference to historical situations and the requirement of justice of the rule of law could not be used to set aside legal certainty as a basic guarantee of the rule of law". The Court therefore considered it impossible to appeal to "the unique historical circumstances of the transition", and refused to suspend the constitutional requirements on the basis of the exceptional nature of the circumstances which would, according to its

\footnotetext{
${ }^{26}$ Recalling the position of the Czech Constitutional Court on the relationship between law and justice and between formal and material rule of law, the president of this court also refers to the Radbruch formula. See Rychetský, op.cit. note 20,158-160. Another decision regarding transitional justice in which the Court continued to be consistent with its past case law is Pl.ÚS 3/14 of 20 December 2016.

${ }_{27}$ Peter Paczolay, "The Hungarian Constitutional Court's efforts for legal certainty", in Sovdat, op.cit. note 6, 168, referring in general to Hungarian constitutional case law, states that this Court "interpreted legal certainty both from its substantial and procedural aspect. However, the Court was criticized for giving priority to formal-procedural elements in case of conflict... The Court was firm in underlying that the basic guarantees of rule of law cannot be set aside by reference to historical situations and to justice...". Following Paczolay, the focus on the formal aspect of the rule of law was highly relevant "in changing the former socialist patterns of legislative activity".

28 The time limits for the limitation period should have begun to run again on 2 May 1990 for crimes of betrayal, voluntary murder and inflicting wounds that caused death, but only in cases in which "state failure to prosecute these crimes was based on political reasons".

${ }^{29}$ This was also valid because, in the Hungarian case, there was not formally a new constitution until 2011, and therefore there was a greater sense of legal continuity.

30 "Legal certainty, based on objective and formal principles has priority over justice that is partial and subjective at all times". Legal certainty is the principle applied by the Court in the early years in order to give strong protection to social rights (see decisions nos. 43/1995, 44/1995, 45/1995, 56/1995), to the point where it was accused of rediscovering socialism. Andras Sajó, "How the Rule of Law Killed Hungarian Welfare Reform", 1 East European Constitutional Review (1996), 31.
} 
authors, justify the act. In emphasizing 'procedural' over 'substantive' justice, the Court urged the parliament to reconcile the need for justice with the formal requirements of legality. ${ }^{31}$

This decision was acclaimed within the foreign literature, which identified the Court's discourse with the idiom of liberal constitutionalism and of a 'civilized' rule-of-law state, in opposition to an apparently vindictive and populist parliament. ${ }^{32}$ This is only one of the many decisions in which the Court curbed efforts by the centre-right majority to punish former communists.

This decision is completely opposite to the Czech approach, following which since the limitation periods were part of a deliberate practice of illegality, one could not appeal to the principle of legality to comply with them. An attitude similar to the Hungarian one, that is, a formal interpretation of the rule of law, was held by the Polish Constitutional Tribunal both in decisions concerning reopening the statute of limitations (for example the decision of 25 September 1991 in case No. 6/91, OTK ZU 1991) and in the best known judgment of 11 May 2007, K 2/07 on the lustration law (which was however accompanied by nine dissenting opinions). ${ }^{33}$

After the entry into force of the 2011 Fundamental Law, the formal interpretation of the principle has continued to be crucial in Hungarian case law, ${ }^{34}$ although the new constitution seems to have switched to a material version of the rule of law. In fact, the Fundamental Law no longer pursues formal neutrality in values, because Article $U$ states that a sense of justice in society must be ensured "by making possible the retroactive prosecution of politically motivated crimes committed and not prosecuted during the communist regime" ${ }^{35}$ Article U also provides for collective responsibility, the disclosure of the personal data of former communist leaders, the reduction of these leaders' pensions, and the non-expiry of the statute of limitations for serious crimes committed during communism in the name of the party-state.

The Hungarian Court tried to switch to a more substantive discussion of the rule of law in decision no. 45/2012 (XII. 29), "On the unconstitutionality and annulment of certain provisions of the transitional provisions of the Fundamental Law of Hungary". It noticed that if the constitutional provisions were constantly subject to the Court's scrutiny, thus making the constitution uncertain, this was incompatible with the notion of the rule of law. However, the Court emphasised that constitutional legality is not based solely on procedural requirements but also on substantive ones. In this decision, an interesting reference is made to international law (ius cogens) enriching the material conception of the rule of law. ${ }^{36}$ In decision no. 61/2011, the Court had also held that international law, including fundamental rights under the European Convention

\footnotetext{
${ }^{31}$ For a non-positivist view of the principle, see Judge Sólyom's concurring opinion in decision no.23/1990 (on the death penalty), to which one may add the 'invisible constitution' doctrine. Andras Sajó, "Reading the Invisible Constitution: Judicial Review in Hungary”, 15 Oxford Journal of Legal Studies (1995), 253.

32 E.g., Spencer Zifcak, "Hungary’s Remarkable, Radical, Constitutional Court", 3 Journal of Const. Law in Eastern and Central Europe (1996), 1. See also Tatham, op.cit. note 5, 145-148, in which the author mentions the relevant Hungarian literature and a series of important decisions regarding the interpretation of the rule of law principle. In particular Tatham, 148, underlines that this formalistic approach, which Paczolay considers to be necessary at that time ("the only possible 'objective' interpretative method in the midst of the change of regime"), was in contrast to the approach of the German constitutional court (generally followed) which links right to justice.

${ }^{33}$ On the jurisprudence of the first few years of the Constitutional Tribunal, see Tatham, op.cit. note 5, $175 \mathrm{ff}$.

${ }^{34}$ See, e.g., decision nos. 2/2013, 13/2013, 20/2014, 34/2014, 34/2015, and 1/2017. In decision no.4/2013, the Court deleted a provision of the criminal code on the public use of totalitarian symbols because it defined the type of conduct subject to criminal sanction too broadly and vaguely. That provision was therefore in breach of the principle of the rule of law and of legal certainty.

${ }^{35}$ In addition, Art.R, para.3 of the Fundamental Law stipulates that "The provisions of the Fundamental Law shall be interpreted in accordance with their purposes, the National Avowal contained therein and the achievements of our historical constitution".

36 "Constitutional legality has not only procedural, formal and public law validity requirements, but also substantial ones. The constitutional criteria of a democratic state under the rule of law are at the same time constitutional values, principles and fundamental democratic freedoms enshrined in international treaties and accepted and acknowledged by communities of democratic states under the rule of law, as well as the ius cogens, which is partly the same as the foregoing. As appropriate, the Constitutional Court of Hungary may even examine the free enforcement and the constitutionalization of the substantial requirements, guarantees and values of democratic states under the rule of law."
} 
on Human Rights, could form an inalienable part of Hungarian constitutionalism. With reference to international law, both customary and conventional, the Court has thus sought to reconcile the difficult succession of constitutional orders with its loss of power and the cancellation of previous case law.

From the above, a paradox is clear in the Hungarian case. Until 2010-2011, neither the constitutional text nor the constitutional jurisprudence explicitly referred to a discontinuity of values between the old and the new regime, even though this discontinuity was implicit in the proclamation and implementation of democratic principles (and despite the 'legalistic' view of the Constitutional Court). With the adoption of the Fundamental Law of 2011, the discontinuity of values is used to limit, in fact, the rule of law and the democratic achievements of the post-communist legislatures. ${ }^{37}$ The hypocrisy of the value discontinuity proclaimed in the text is evident; it is a historical nemesis outside time, and therefore 'ahistorical'.

\subsection{An Intermediate Version of the Rule of Law: The Cases of Croatia, Bulgaria and Romania}

The Constitutional Court of Croatia also dealt with transitional justice issues, although Croatia did not adopt a lustration law after the transition from communism, particularly because of the imminent threat of war. There are, however, interesting decisions on the restitution of property and punishment of criminal activities defined as 'war profiteering' and 'crimes related to ownership transformation and privatization'. Significant for the purpose of this review is certainly the decision of 24 July 2015 on war profiteering that involves the former Prime Minister Ivo Sanader (No. U-III-4149/2014). In this case, generally known as the Hypo and INA-MOL case, with reference to the constitutional amendment of 2010 in which Article 31 was supplemented by a new paragraph 4 that excluded the statute of limitations for a series of serious offences, ${ }^{38}$ the Court tried to balance the formal with the material rule of law. It interpreted the new paragraph as allowing, in the future, unlimited time for the criminal prosecution of perpetrators of these crimes, provided that the offences in question were not barred by the statute of limitations on the day of entry into force of the constitutional amendment (16 June 2010). In this manner, "the Croatian Constitutional Court interpreted the constitutional amendments in accordance with the well-known and accepted legal principles of legal certainty and legality, barring the prolongation of the statute of limitations in cases where it had already expired". 39

As far as Bulgaria is concerned, there are many decisions on transitional justice in which the Court deemed the acts under challenge to be contrary to the principle of the rule of law. An example is the decision of 21 January 1999 (judgment no. 02/99) in a case in which a wide-ranging amendment to the Act on Administration adopted in May 1998 was challenged before the Court. The amended act would have prevented all former senior officials of the Communist Party, or officers or employees of the security services regardless of category, from holding senior governmental or public administration offices for five years. The Court, answering an application from a group of deputies, deemed the law to be contrary to the principle of the rule of law (Articles 4, 6.2 and 38 of the Constitution), stating that guilt and responsibility must be individual and not collective. These lustration provisions were also at odds with a number of international documents and instruments to which Bulgaria was a party.

One of the most interesting decisions is order no. 12 of 13 October 2016 (case 13/2015). The applicant (the Attorney General of the Republic) had challenged an amendment to the criminal code of 2015 that had

\footnotetext{
${ }^{37}$ For a survey of the case law following the adoption of the FL, see Eszter Bodnár, Fruzsina Gárdos-Orosz, Zoltán Pozsár-Szentmiklósy, "Hungary", 2016 and 2017 Global Review of Constitutional Law.

${ }^{38}$ Stating that "The statute of limitations shall not apply to the criminal offences of war profiteering, nor any criminal offences perpetrated in the course of economic transformation and privatization and perpetrated during the period of the Homeland War and peaceful reintegration, wartime and during times of clear and present danger to the independence and territorial integrity of the state, as stipulated by law, or those not subject to the statute of limitations under international law. Any gains obtained by these acts or in connection therewith shall be confiscated."

${ }^{39}$ Sanja Barić, The Transformative Role of the Constitutional Court of the Republic of Croatia: From the ex-Yu to the EU (Analitika, Sarajevo, 2016), 19. Following the author, the ruling was widely criticized and the Court was accused of politicization.
} 
introduced new cases for which the statute of limitations was eliminated - a series of offences (with reference to the relevant articles of the code) committed during the communist regime. The statute of limitations was completely removed for these offences, in the same way as for crimes against humanity. The Bulgarian Constitutional Court considered that the retroactive removal of the statute of limitations for crimes committed but not punished under the communist regime was not permissible in light of the constitutional principle of the rule of law. It also considered that the crimes in question could not be assimilated to crimes against humanity, as had been argued by human rights associations.

This decision is therefore different from that of the Czech Constitutional Court (1993), but at the same time is not comparable to that of the Hungarian Constitutional Court (1992), because the Bulgarian Court concluded that it was possible, in principle, for the legislature to abolish the statute of limitations for crimes other than crimes against humanity, especially if the crimes were committed during the totalitarian period. However, it censured the way in which the act pursued this goal, considering it in conflict with several elements of the rule of law (lack of clarity: the type of crimes or the guilty persons were not well defined, because the wording used was indeterminate). Therefore, the Bulgarian Constitutional Court essentially adopted a mixed interpretation, both formal and substantive, of the rule of law, and annulled the act being contested simply for breach of this principle.

As far as Romania is concerned, the Constitutional Court rejected a draft law on lustration in its entirety in decision no. 820 of 7 June $2010 .^{40}$ The Court considered the draft law to be unconstitutional because it breached both Article 1, paragraph 3 of the Constitution on the rule of law, which had been cited by the applicants (29 senators), and other constitutional provisions, including those specifying the different components of the rule of law, such as non-retroactivity of the law, non-discrimination, amongst others. In this case, as with the Bulgarian Constitutional Court's decision on the statute of limitations discussed above, the purpose of the law was not considered wrong, although after so many years it no longer made sense to conduct lustration. Above all, the Court criticized the law's lack of clarity.

\section{The Rule of Law and European Integration}

As regards EU integration, the democratic conditionality process was developed precisely in view of the 'great' enlargement to the countries of Central and Eastern Europe whose application process was much more complex than in the past. In turn, the constitutions of the candidate countries have been equipped, from the beginning or through subsequent constitutional amendments, to face the impact of international and European law by providing special clauses for the transfer or delegation of certain sovereign powers and related safeguard clauses. ${ }^{41}$

As regards the attitude of their constitutional courts, generally, despite being very eurofriendly before entry to the EU, they then became jealous of sovereignty. According to Bobek, this is explained by the fact that while they had been among the protagonists of the post-transition path, enjoying high prestige, with the entry of the relative countries into the EU their role has been reduced ${ }^{42}$ leading to understandable reactions. ${ }^{43}$ But according to other authors this attitude, if intended to protect fundamental rights and the national popular

\footnotetext{
40 This decision ruled on the unconstitutionality of the provisions of the law of lustration that provided for a temporary restriction on access to certain public offices for people who were part of the power structure and repressive apparatus of the communist regime between 6 March 1945 and 22 December 1989. Subsequently a new draft, which merely introduced amendments to the previous one and was adopted on 28 February 2012, was submitted for review by the Court and was also rejected, by decision no.308 of 28 March 2012.

${ }^{41}$ See Angela Di Gregorio, Riforme costituzionali ed integrazione europea: il caso dei nuovi membri dell'Est, 4 Diritto pubblico comparato ed europeo (2004), 2067-2093; Anneli Albi, EU Enlargement and the Constitutions of Central and Eastern Europe (CUPress, Cambridge, 2005); Id., "Europe" Articles in the Constitutions of the Central and Eastern European Countries", 42 (2) CMLRev (2005), 399-423.

${ }^{42}$ E.g.: questions can be brought to the European Court of Justice even bypassing them.

${ }^{43}$ They scrutinized EU secondary legislation and even declared an act of UE law ultra vires. Michal Bobek, op.cit. note $5,412-416$.
} 
representation, is not a form of state resistance to the processes of supranational integration, but rather a "rigorous affirmation of popular sovereignty". ${ }^{44}$ It means that the fixing of limits should not be considered as an anachronistic and closed sign of a belief in sovereignty, but rather as an attempt to put the focus on individuals and their fundamental rights. ${ }^{45}$

References to a 'rule-of-law state' or 'democratic law-based state' are recurrent in the case law of the constitutional courts of the new EU member states when they are dealing with the penetration of European law into domestic law. These references are used mainly to dictate the limits of that penetration ${ }^{46}$ (as in some old member states of the EU), ${ }^{47}$ but also to justify European integration. The most significant decisions are those of the Czech Constitutional Court and the Supreme Court of Estonia, but some inspiration also comes from the Latvian and Romanian Constitutional Courts. Unlike the decisions on transitional justice issues, the courts in these cases did not consider the rule of law to have been violated.

As regards the Czech Republic, there are many decisions in which the Constitutional Court has taken a stand against European law, seeing limits to its entry into the domestic legal order. In general, one can observe that, except for the Holubec-Landtová case ${ }^{48}$ (whose rationale, as many local scholars have noticed, can be explained in light of the domestic confrontation between the Constitutional and the Supreme Administrative Courts) ${ }^{49}$, the attitude of the Czech Constitutional Court has been favorable to European integration $^{50}$ while setting clear - but reasonable - limits on how far European law can go. ${ }^{51}$

There are some well-known decisions in which the CCC made reference to the democratic state based on the rule of law which should be read in connection with those regarding the limits on constitutional amendments. In fact, the constraints on constitutional amendments and the limits on the penetration of

\footnotetext{
${ }^{44}$ Massimo Luciani, "Il brusco risveglio. I controlimiti e la fine mancata della storia costituzionale", 2 Rivista AIC (2016), 7, available at <www.rivistaaic.it/il-brusco-risveglio-i-controlimiti-e-la-fine-mancata-della-storia-costituzionale.html>.

45 Anneli Albi, "Erosion of Constitutional Rights in EU Law: A Call for "Substantive Co-operative Constitutionalism". Parts I and II, 9 (2) and 9 (3)' Vienna Journal of International Constitutional Law (2015) 151 and 291. By the same author, see "Supremacy of EC Law in the New Member States. Bringing Parliaments into the Equation of "Cooperative Constitutionalism", 3 European Constitutional Law Review (2007), 25 and "An Essay on How the Discourse on Sovereignty and on the Co-operativeness of National Courts Has Diverted Attention from the Erosion of Classic Constitutional Rights in the EU”, in Monica Claes, Maartje de Visser, Patricia Popelier, Catherine Van de Heyning (eds.), Constitutional Conversations in Europe (Intersentia Publishing, Cambridge, 2012).

${ }^{46}$ As noted by Sadurski, there is a sort of paradox in these states' desire to defend their fundamental constitutional values while the entry into the EU has been seen just as a guarantee of the continuation of democratic choice. Wojciech Sadurski, Constitutionalism and the Enlargement of Europe (OUP, Oxford, 2012), 208-209.

${ }^{47}$ The first constitutional court to elaborate the counter-limits doctrine was the Italian one in 1973 (Frontini case). See Marta Cartabia, "The Italian Constitutional Court and the Relationship Between the Italian Legal System and the European Union", in Anne-Marie Slaughter, Alec Stone Sweet, Joseph H.H. Weiler (eds.), The European Courts \& National Courts. Doctrine and Jurisprudence (Hart Publishing, Oxford, 1998); Giulio Itzcovich, "Sovereignty, Legal Pluralism and Fundamental Rights. Italian Jurisprudence and European Integration (1964-1973)", 10 (1) European Public Law (2004), 107-133; Angela Di Gregorio, "Constitutional Law and European Integration: the Italian Case", 1 Analele Universităţii din Bucureşti Seria Drept (2013), 1-15.

${ }^{48} \mathrm{Pl}$. ÚS 5/12 of 31 January 2012.

49 Jan Komárek, "Czech Constitutional Court Playing with Matches: The Czech Constitutional Court Declares a Judgment of the Court of Justice of the EU Ultra Vires; Judgment of 31 January 2012, Pl. ÚS 5/12, Slovak Pensions XVII", 8 European Constitutional Law (2012), 323; Michal Bobek, "Landtová, Holubec, and the Problem of an Uncooperative Court: Implications for the Preliminary Rulings Procedure", 10 European Constitutional Law Review (2014), 54; Jiří Příbáň, "Constitutional Sovereignty in Post-sovereign Jurisprudence of the Czech Constitutional Court: From the Lisbon Judgments to the Landtová Ultra Vires Controversy", in Bobek op.cit. note 5, 323.

${ }^{50}$ This can especially be seen in the decision about the 5\% threshold of the European electoral law. See Hubert Smekal and Ladislav Vyhnánek, "Equal Voting Power under Scrutiny: Czech Constitutional Court on the 5\% Threshold in the 2014 European Parliament Elections: Czech Constitutional Court 19 May 2015, Pl. ÚS 14/14", 1 European Constitutional Law Review (2016), 148.

51 On the topic, in general, see Pavel Molek, "The Czech Constitutional Court and the Court of Justice: Between Fascination and Securing Autonomy", in Claes op.cit. note 47.
} 
European law coincide, as the Court stated in its judgment on the early termination of the legislature, Pl. ÚS $27 / 09$ of 10 September 2009.52

In the judgment on the European Arrest Warrant (Pl. ÚS 66/04 of 3 May 2006), there was only limited reference to the rule of law. More explicit was the judgment Pl. ÚS 50/04 of 8 March 2006, the so-called Sugar Quotas III decision, which dealt with the limits and conditions for the penetration of EU law. According to the Court, there are no provisions of international or EU law that could be superior to the Constitution in the Czech constitutional order. Although the Constitution allows for the delegation of certain powers of the Czech authorities to an international organization, such delegation is only conditional and may only exist "so long as these powers are exercised in a manner that is compatible with the preservation of the foundations of state sovereignty of the Czech Republic, and in a manner which does not threaten the very essence of the substantive law-based state". According to Article 9, paragraph 2 of the Constitution, the essential attributes of a democratic state governed by the rule of law remain beyond the reach of the constituent assembly itself. The Court again mentioned the first plenary decision Pl. ÚS 19/93 and expressly declared that "in the framework of this Constitution, the constitutive principles of a democratic society are placed beyond the legislative power and are thus ultra vires the Parliament....Should, therefore, these delegated powers be carried out by the EC organs in a manner that is regressive in relation to the existing conception of the essential attributes of a democratic law-based state, then such exercise of powers would be in conflict with the Czech Republic's constitutional order, which would require that these powers once again be assumed by the Czech Republic's national organs. In the specific case before the Court, however, such a situation was not generally present...”.

The discussion of the principle of the rule of law in the first decision on the Lisbon Treaty (Lisbon I), of 26 November 2008, is equally broad. ${ }^{53}$ In its petition, the Senate referred to Articles 1 and 9 of the Constitution and therefore to the principle of the rule of law. The Court established that the rule of law is an obstacle to limitations on sovereignty that may lead to a violation of the fundamental principles of a democratic state governed by the rule of law, reiterating the same concepts expressed in its judgment Pl. ÚS 50/04. However, according to the Court, sovereignty today can no longer be understood as having an absolute nature because it is more a practical notion. In this regard, "the Treaty of Lisbon is consistent with the untouchable principles protected by the Czech constitutional order and European law is based on fundamental human and democratic values, common to and shared by all EU states". As far as the second decision on the Lisbon Treaty (Lisbon II), of 3 November 2009, is concerned, ${ }^{54}$ the group of senators who had filed the appeal envisaged a violation of the principle of the democratic state based on the rule of law, that is, of Article 1, paragraph 1 of the Constitution. However, the Court did not rule on this aspect of the application, intending that its previous judgment on the topic was sufficiently clear.

\footnotetext{
${ }^{52}$ In this decision, the first in which the Court considered the constitutionality of a constitutional act, the Court affirmed that the principle of the generality (abstract nature) of the law is an essential requirement of a democratic state based on the rule of law, under Art. 9, para. 2 of the Constitution, and therefore that it is part of the material core of the Constitution. While the legislature may derogate under certain conditions from the principle of the generality of the law, constitutional acts may be adopted for a specific case only in exceptional circumstances (state of war, natural disaster, and other cases), in order to protect the material core of the Constitution. On the Czech concept of "material core" of Constitution see Pavel Molek, Materiální ohnisko ústavy: véčný limit evropské integrace? (Material Core of Constitution - an Eternal Obstacle to EU Integration?), Edice Scientia, Brno, 2014.

${ }^{53}$ Pl. ÚS 19/08: Petition from the Senate of the Parliament of the Czech Republic, seeking review of whether the Treaty of Lisbon amending the Treaty on European Union and the Treaty establishing the European Community is consistent with the constitutional order of the Czech Republic.

${ }^{54} \mathrm{Pl}$. ÚS 29/09: Petition from a group of senators of the Senate of the Parliament of the Czech Republic for review of the Treaty of Lisbon amending the Treaty on European Union and the Treaty establishing the European Community for conformity with the constitutional order. Jiř́ Zemánek, "The two Lisbon judgments of the Czech constitutional court", in José M. Beneyto and Ingolf Pernice (eds.), Europe's constitutional challenges in the light of the recent case law of national constitutional courts (Nomos, Baden-Baden, 2011).
} 
The judgment of the Supreme Court of Estonia of 12 July 2012 on the European Stability Mechanism (ESM) is also worthy of consideration. ${ }^{55}$ The Supreme Court, although considering that the mechanisms created by the contested provision violated some important constitutional principles including the rule of law (which is formally enshrined in Article 10 of the Constitution but is also implicit in other articles, namely Article 1, para. 1 and Article 3, para. 1), ultimately decided that this violation was not serious. In this case, the reference to the rule of law was used more widely by the applicant and by the dissenting judges than by the Court, which, in the end, did not consider the principle to have been 'significantly' violated (a highly ambiguous phrase) because it must be balanced with other constitutional principles.

The Court linked the principle of the rule of law to the democratic principle (in the same way as did the Czech Constitutional Court) ${ }^{56}$ and considered that "the principle of a democratic state subject to the rule of law means that the general principles of law that are recognised in the European legal space are valid in Estonia (judgment of the Constitutional Review Chamber of the Supreme Court of 17 February 2003 in case no. 3-4-1-1-03, point 14)".

Following the Court's reasoning, by ratifying the ESM Treaty the parliament restricted its own future possibilities, and those of future parliaments, in relation to budgetary actions. Although the article of the Treaty that was being challenged interferes with the principle of a democratic state subject to the rule of law and the principle of sovereignty that come from the preamble and Article 1 of the Constitution, "the economic and financial sustainability of the euro area is contained in the constitutional values of Estonia as of the time Estonia became a euro area member state" and also in the $2003 \mathrm{EU}$ entry referendum the people had already agreed to these subsequent developments (an assertion doubted by the dissenting judges).

Among the most obscure points of the judgment is the one in which the Court considered that ratification of the Treaty did not interfere seriously with some fundamental constitutional principles such as the rule of law and sovereignty but, at the same time, that the measures to implement the Treaty, including the way in which the funds required by the ESM would be paid, could cause such a violation. For this reason, the Court intended to monitor the implementation measures. Finally, by linking the ESM mechanism to EU law (which seems to be clear from the outset), the Court established the possibility that counter-limits/reservations could be triggered. ${ }^{57}$

As for Latvia, we can mention the judgment on the Lisbon Treaty of 7 April 2009, in which the Constitutional Court decided that the Treaty was consistent with the Constitution, but established some conditions. ${ }^{58}$ The Court recognized that the state of Latvia is based on fundamental values such as human rights and fundamental freedoms, democracy, the sovereignty of the state and its people, the separation of powers and the rule of law. According to the Court, "the state has the duty to guarantee these values and they cannot be infringed by introducing amendments to the Satversme, these values being introduced by law. Consequently, delegation of competencies cannot exceed the rule of law and the basis of an independent, sovereign and democratic republic based on the basic rights. Likewise, it cannot influence the right of citizens to decide upon the issues that are substantial for a democratic state". Recalling what was said in the

\footnotetext{
${ }^{55}$ No.3-4-1-6-12. The applicant, the Chancellor of Justice, considered Art. 4(4) of the Treaty establishing the European Stability Mechanism, signed on 2 February 2012 in Brussels, to be in conflict with the Constitution.

56 "The principle of democracy is aimed at the legitimacy of the public authority, containing formation, legitimation and supervision of public bodies, and affecting all stages of formation of a political will. The principle of a democratic state subject to the rule of law, on the other hand, governs the content, extent and manner of the functioning of political authority".

57 "...If it becomes evident that the new founding treaty of the European Union or the amendment to a founding treaty of the European Union gives rise to a more extensive delegation of the competence of Estonia to the European Union and a more extensive interference with the Constitution, it is necessary to seek the approval of the holder of supreme power, i.e. the people, and presumably amend the Constitution once again. These requirements are to be considered also if the Treaty leads to amendments to the TFEU and TEU." For for a reasoned critique of the judgment see Carri Ginter, "Constitutionality of the European Stability Mechanism in Estonia: Applying Proportionality to Sovereignty", 9(2) European Constitutional Law Review (2013), 335-354.

${ }^{58}$ Judgment of the Constitutional Court of Latvia in case no.2008-35-01 of 7 April 2009.
} 
judgment of 14 September 2005 in case no. 2005-02-0106, the Court also underlined that the binding nature of international legal acts protecting human rights and fundamental freedoms is a part of the principle of the rule of law.The fact that the Charter and the ECHR would become binding on the EU according to Article 6 (2) and (3) of the CTEU is not incompatible with the Satversme because all of these documents are based on the same values and principles. Moreover, the Court has repeatedly stated that the objective of the legislator was not to contrast the human rights norms established in the Satversme with international legal norms. The Satversme in essence cannot envisage a lesser degree of ensuring or protecting fundamental rights than is envisaged in any international legal acts. A different conclusion would be contrary to the idea of the state based on the rule of law as established in Article 1 of the Satversme. One of the main features of a state based on the rule of law is recognition of human rights and fundamental freedoms as the highest values.

Turning now to Romania, with decision no. 80 of 16 February 2014 the Constitutional Court ruled on a draft for broad constitutional reform, declaring it unconstitutional. In several respects, the Court found that the proposed amendments violated the principle of the rule of law. For example, the Court considered the modification of Article 148, paragraph 2, which would have given European law supremacy even over the Constitution, ${ }^{59}$ to be inconsistent with the principle of the rule of law referred to in Article 1, paragraph 2 of the Constitution. This is because constitutional provisions are not declaratory but binding, and, therefore, the supremacy of European law cannot be established at the constitutional level, as the Constitution itself, in a series of articles (Articles 1, 3 and 5, and Article 20, para. 2), clearly provides a sub-constitutional ranking for international treaties. ${ }^{60}$ Therefore, the Court, unanimously, found that the amendment to the provisions of Article 148 (2) was unconstitutional, since it violated the limits for revisions referred to in Article 152 (2) of the Constitution.

The Constitutional Court of Lithuania, in its rulings of 24 January 2014 and 11 July 2014, stated that it is forbidden to adopt constitutional amendments that might be contrary to the international obligations of the country. This is also deduced from the constitutional principles of the rule of law and pacta sunt servanda.

\section{The Rule of Law and Separation of Powers, Particularly the Independence of the Judiciary}

The separation of powers is not always included within the principle of the rule of law but, in any case, it is emphasized in post-communist constitutions. With particular reference to the independence of the judiciary, this is a topic that has begun to develop quite recently in the constitutional case law of the new EU members, since in the first few years after the transition to democracy the constitutional courts were dealing with politically active powers.

The most relevant case law regarding the independence of the judiciary comes from the Slovak and Slovenian Constitutional Courts. Taking the Slovak Constitutional Court first, in its decisions on this topic it has adopted an openly material interpretation of the rule of law. For example, in judgment PL. ÚS 17/2008 of 20 May 2009, in which the Court considered the foundation of special jurisdictions as unconstitutional because it contradicted the substantive principle of the rule of law (referring to Czech case law and

\footnotetext{
59 The proposed version stated: "Romania shall ensure observance, within its national legal order, of the European Union law, according to the obligations undertaken through the accession document and the other treaties signed within the Union". The original, and current, version of the Article states: "As a result of the accession, the provisions of the constituent treaties of the European Union, as well as the other binding community regulations shall take precedence over the opposite provisions of the national laws, in compliance with the provisions of the accession act". The amended version would have meant that European law had supremacy over the national Constitution as well.

60 "By establishing that the European Union law applies without any circumstantiation within the national legal order, the fact of making no distinction between the Constitution and the other domestic laws is equal to placing the Basic Law in the background compared to the legal order of the European Union. From this perspective, the Court holds that the country's Basic Law - the Constitution - is the expression of the people's will, which means that it cannot lose its binding force through the simple existence of a non-concordance between its provisions and European ones. Likewise, the accession to the European Union cannot affect the Constitution's supremacy over the entire legal order (see, to the same purpose, Ruling of 11 May 2005, K 18/04, issued by the Constitutional Tribunal of the Republic of Poland)".
} 
literature $)^{61}$, the Court ruled that "the material rule of law is not based on an apparent observance of the law or on the formal respect of its content in a way that feigns compatibility of legally relevant facts with the law. The essence of the material rule of law lies in placing the applicable law into conformity with the core values of a democratically organized society and subsequently in consistent application of the law in force without exceptions based on purposive reasons." In this case, the Court admitted the possibility of repealing an act solely because it violated the principle of the rule of law "in the situation where the breach of the principles of material rule of law is so serious that in itself it must lead to a decision on nonconformity of the law with the Constitution". 62

Repealing an act on the basis of a direct breach of the principle of the rule of law was carried out also in judgment PL. ÚS 12/05 of 28 November 2007, concerning the status of judges and their salaries, which had been reduced because of the economic crisis. The act in question "is not consistent with Article 1, para. 1 of the Constitution of the Slovak Republic together with Article 144, para. 1". In fact, "it is undisputed that the principle of judicial independence is one of the essential elements of a democratic state governed by the rule of law (Article 1, para. 1), stemming from the neutrality of judges as a guarantee of fair, impartial and objective court proceedings. This principle contains a number of aspects which together create the conditions enabling the courts to perform their tasks and duties primarily in protecting the fundamental rights and freedoms of citizens. It is based on the independence of courts (Article 141, para. 1) and of judges (Article 144, para. 1). The independence of judges in a broader sense, however, must also be understood as their material independence".

Turning to Slovenia, in decision U-I-159/08 of 11 December 2009 the Constitutional Court ruled on the independence of the judiciary as part of the principle of separation of powers, which is, in turn, considered to be related to (but not part of) the principle of the rule of law. In particular, the Court was called upon to adjudicate on the economic aspect of that autonomy (adequacy of salary and reduction because of the economic crisis). ${ }^{63}$ Almost all the contested provisions were declared to be inconsistent with the Constitution. The Court ruled in this case that "the principle of the separation of powers is a fundamental principle of the organization of the state power. Due to the fact that this is one of the fundamental principles of the constitutional system, its full effect, especially from the viewpoint of the position and functions of the judicial power, must be understood in connection with other fundamental constitutional principles, such as the principle of democracy (Article 1) and the principle of a state governed by the rule of law (Article 2)". The Court also emphasized the importance of the enforcement of the rule of law by judges. ${ }^{64}$

In decision U-I-60/06 of 7 December 2006, the Slovenian Constitutional Court was forced to defend the role of the Constitutional Court, again referring to the rule of law and the separation of powers (a similar

\footnotetext{
${ }^{61}$ Slovak legal scholars and judges often refer to the Czech literature. The report/questionnaire for the September 2017 Vilnius Conference, 3, fn. 2 (available at <www.wccj2017.lt/data/public/uploads/2017/01/slovakia-constitutional-courten.pdf $>$ ) states that "when outlining this classification of constitutional principles, we use as our source the Czech legal theory, whose conclusions are also applicable to the Slovak Republic", quoting Jan Filip, Ústavní právo. 1 Základní pojmy a instituty, Ústavní základy $\check{C} R$ [Constitutional Law. Vol. 1. Basic Concepts and Institutions. The Constitutional Foundations of the Czech Republic] (Masarykova Univerzita, Brno, 1999). See also Alexander Bröstl et al., Ústavné právo Slovenskej republiky [Constitutional Law of the Slovak Republic] (Aleš Čeněk, Praha, 2010) and Ján Drgonec, Ústava Slovenskej republiky. Teória a prax [Constitution of the Slovak Republic. Theory and practice] (C.H. Beck, Bratislava, 2015).

62 "The establishment of a state body that by its nature lies outside the standard organization of public authorities in the state, without there being any compelling reason justifying the establishment of such a body, in itself seriously threatens the essence of the material rule of law. For that reason the establishment of such a body is incompatible with the protection guaranteed by Art. $1 \mathrm{sec} .1$ of the Constitution within the scope of the principles of the rule of law (accordingly e.g. PL. ÚS 6/04)".

${ }^{63}$ The Constitutional Court was asked by the Administrative Court to judge the constitutionality of several provisions of the Act on the salary system in the public sector, in relation to judges, and also of the Judicial Service Act.

64 "An exceptionally important position of the judicial power within the framework of the principle of the separation of powers must therefore follow from the fact that the judicial power plays the key role in implementing the principles of a state governed by the rule of law".
} 
decision was adopted by the Constitutional Court of Croatia in 2014) ${ }^{65}$ stating that "The principles of a state governed by the rule of law (Article 2 const.) and the principle of the separation of powers (Article 3, para. 2) require, inter alia, that each of the branches of power performs their powers and can be held to account for the (non)performance of such. If the legislature does not respond to the Constitutional Court decision, which is binding on the legislature (Article 1, para. 3), within the period of time determined by the Constitutional Court for it to remedy the established inconsistencies and does not try to remedy the inconsistencies, the legislature thereby violates Article 2 and the second paragraph of Article 3 of the Constitution".

The Supreme Court of Estonia, in decision 3-4-1-1-14 of 26 June 2014, declared provisions concerning the reduction of judges' pensions (modifying the calculation of their retirement pensions) to be unconstitutional, and in decision 3-4-1-21-15 of 22 October 2015 it declared provisions limiting the amount of pension granted to survivors (widows' pensions) to be unconstitutional. In both cases it held that there was a breach of the principle of legitimate expectations, which is a component of the rule of law.

The principle of 'constitutional loyalty', as an element of the separation of powers, was discussed by the Romanian Constitutional Court in its decision no. 972 of 21 November 2012. The case concerned a conflict between the judicial authority and the Senate, which had voted against the enforcement of a judgment of the High Court of Cassation and Justice, although the judgment confirmed, irrevocably, that Senator Mircea Diaconu was ineligible to stand as a senator. The Court ruled in favour of the applicant (the President of the Superior Council of Magistracy), stating that "to deprive a final and irrevocable judgment of its enforceability is a violation of the legal order of the rule of law and of the good operation of justice". And also "...submitting to the debate the civil sentence no. 5153 of 16 September 2011 of the Court of Appeal...the Senate has acted as a higher court, which affects the fundamental principle of the rule of law, namely the principle of separation and balance of powers - legislative, executive and judicial - within constitutional democracy, enshrined in Article 1(4) of the Basic Law". In the end, the Court stressed the relevance of the proper functioning of the rule of law and of cooperation between state powers, which should be manifested in the spirit of constitutional loyalty, with the loyal behaviour being an extension of the principle of the separation and balance of powers.

\section{Concluding Remarks}

The constitutional courts of the new EU member states refer broadly to the principle of the rule of law when addressing a wide spectrum of issues. Although in some cases it is believed that reference to the principle prevailed in the period immediately following the transition to democracy, ${ }^{66}$ an analysis of more recent case law shows that the rule of law continues to be a point of reference in an extensive series of issues. Apart from the formal aspects of the principle, that is, the features of the law (legal certainty, ${ }^{67}$ nonretroactivity, clarity and non-contradiction, proportionality, legitimate expectations), the more sensitive issues concern transitional justice and European integration.

In the first case, the introduction of transitional justice measures has been a (perhaps) unsuccessful attempt to cope with the social need for the cleansing of the past, at the same time upholding the rule of law principle. The synthesis of these two needs seems to have been almost impossible. As noted by the German

\footnotetext{
65 See decision U-I - 5735 / 2014 of 12 August 2014, in which the Court considered failure to grant constitutional judges the supreme state protection granted to officials/members of other public bodies to be inconsistent with the separation of powers.

66 In answering the questionnaire that was prepared for the 2017 Vilnius Conference (available at <www.wccj2017.lt/data/public/uploads/2017/01/estonia-supreme-court-en.pdf $>$ ), the Supreme Court stated that "At present the Supreme Court does not have to deal very often with the questions of whether the state follows the basic requirements arising from the rule of law...it had to address such questions particularly after the Republic of Estonia regained its independence and after the change in the legal order in the 1990s, when the Supreme Court was also reestablished. However, the legal order has developed over time and the need for such decisions has gradually decreased". ${ }^{67}$ In general, the need for legal certainty prevails. This is partly explained by the desire to break away from the past, but also from the mistakes of the new legislatures, and hence, from the shortcomings of legislative drafting.
} 
dissident Bärbel Bohley, "we were expecting justice, but we got the rule of law" ${ }^{68}$ The main dilemma was the confrontation between different constitutional values: the requirements of 'legitimacy' and 'legality' have frequently and inevitably resulted in a conflict situation. As the Czechoslovak, and then the Czech Constitutional Courts considered, by echoing the German case law, ${ }^{69}$ while the principle of legality is based on the continuity of the state and its laws, the development of democracy requires a line of separation between the totalitarian regime and its legal system and the democratic one. ${ }^{70}$ This certainly applies to the period immediately following the transition, but many years later the adoption of such measures can no longer be explained by referring to the rule of law. At the same time, the role of constitutional courts in transitional circumstances is highly sensitive, especially in the former communist countries where they are not always respected by politicians and the general public. ${ }^{71}$

As for EU integration, a possible violation of the rule of law has been invoked by applicants while constitutional courts have mostly upheld - under certain conditions - the validity of European law. A comparison between the case law of the Czech Constitutional Court and the Estonian Supreme Court suggests that while in the first case constitutional values — and the rule of law in particular - constitute an imperative limit both to the limitation of sovereignty and to constitutional amendments, the Estonian Supreme Court seems to follow a more flexible approach since the need to respect its international commitments can justify some limited violations of the rule of law. However, in balancing two values equally deserving of protection in both cases, the courts have raised the possibility of activating the counterlimits for possible violations of constitutional values although in the specific cases addressed they did not recognize risks of a serious breach.

Emphasis on values such as human dignity, freedom, and justice, and on principles such as popular sovereignty, the rule of law, and representative democracy, is more important for these courts than for those of the older democracies. ${ }^{72}$ Additionally, this emphasis has not diminished over time, which means either that there is a greater primary sensitivity to these values, or that these democracies are still partially in transition. $^{73}$

${ }^{68}$ Reported in James A. McAdams, "The Honecker Trial: The East German Past and the German Future", 58 The Review of Politics (1996), 53. According to Jon Elster, new democracies could solve the contrast between procedural and substantive justice in three different ways: claiming to respect fundamental legal principles; openly agreeing on the necessity, in an unprecedented situation, of violating those principles; trying to achieve both things. See Jon Elster, Closing the Books. Transitional Justice in Historical Perspective (CUP, Cambridge, 2004).

${ }^{69}$ In a case decided by a judgment of 24 October 1996, the first instance court focused on the principle of nonretroactivity of criminal law. In that regard, as in the post-nazi period, the court chose to give precedence to substantive justice or Gerechtigkeit, considered to be one of the fundamental principles of the rule of law. In the words of the court, the GDR put in place 'an extreme state injustice' (extremes staatliches Unrecht); the subordination of the right to life of the individual to the national interest to prevent the crossing of the border put the written law behind the demands of political opportunity. It was therefore the most serious substantive injustice (material schwerstes Unrecht).

${ }^{70}$ Jiř́i Malenovský, "Les lois de "lustration" en Europe centrale et orientale: une "missione impossibile"?", 13 Revue québécoise de droit international (2000), 188.

${ }^{71}$ As noted, "In all of the so-called states in transition, there namely existed — to a greater or lesser extent—social and political realities that were different than the one in which the first constitutional courts were established after 1920 and in which the constitutional judiciary spread throughout Western Europe following the Second World War". See Ernest Petrič, "The role of Constitutional Courts in the implementation of the rule of law in states in transition", in Sovdat, op.cit. note $5,172$.

${ }_{72}$ As stated by Thomas von Danwitz, 'The Rule of Law in the Recent Jurisprudence of the ECJ', 37 Fordham International Law Journal (2014), 1311 ff., the old EU member states have never been concerned about the protection of a principle that they took for granted, making a serious mistake because the protection of this principle is always at risk even in established democracies, and there is a need for strong judicial protection of it.

${ }^{73}$ E.g., when considering the stability of institutional relations, as the Slovak Constitutional Court affirmed in a 2014 decision (PL. ÚS 102/2011 of 7 May 2014): “...we still find ourselves in a transitional or post-transitional democracy, since we are still building and rebuilding the institutional system of public authorities...in times of post-transitional democracy it must be acknowledged that the legislator still seeks the optimal model of public authorities by identifying and correcting the shortcomings of the previous one...". The Court expressed a clear self-restraint towards the executive and legislative powers: "In times like these, the Constitutional Court must in a way exercise more self-restraint in 
The jurisprudence of the constitutional courts also makes us understand the culture of the rule of law in their respective countries and the models that they followed. In fact, although the content of the rule of law is inspired by European models (especially the German model), in some ways the resemblance is only formal and covers many cultural differences. ${ }^{74}$ At the same time, European conditionality mechanisms have not particularly supported these countries, and their courts, to make the concept of rule of law clearer. Among the limits of the democratic conditionality process, one can include lack of clarity in identifying the different values on the basis of abstract categories such as democracy and the rule of law, ${ }^{75}$ apparently considering the triad 'rule of law, democracy and human rights' as a monolithic notion.

After so many years following the transition to democracy, can we still categorize these countries in a single nucleus, or can we extend the comparisons in a transverse way as various different authors suggest? $?^{76}$ Indeed, as we have seen, the challenges faced by these countries, and therefore by these constitutional courts, are many (especially the emphasis on values and regime discontinuity), although they have different nuances. At the same time, if the issues stemming from the past are peculiar to these countries, other issues, such as the defence of constitutional identity, are now widespread among all the EU members. ${ }^{77}$ Moreover, with the EU's enlargement to the East, there has not only been a translation of principles, rules, and models from West to East, but also the opposite, even if the discussion on this aspect is limited ${ }^{78}$ (without considering recent studies concerning the circulation of populist ideas - the so-called 'populist international' - in the different regions of the European Union).

As regards the specific contents of a concept that is still vague and potentially all-encompassing, analysis of the jurisprudence of these countries can also be profitable considering that, as mentioned above, the strong imprint of Western models is joined by still deeply rooted internal motivations that lead to enhancing some aspects / values compared to others (this is particularly evident in transitional justice issues). The former communist countries represent good examples of the difference between formal and substantive rule of law,

interfering with the powers of the legislative assembly from its position of a negative legislator (even more so when the Court acts in the position of a positive legislator). This does not mean that the Court should renounce its role of the guardian of constitutionality; it merely means that the Court should in a sense be more prudent".

${ }^{74}$ Among the peculiarities of former communist countries in that regard are: the loss of social cohesion due to the collapse of communist solidarity, the advent of a savage market that has produced many injustices, the suffering of the older generation, coexistence with ethnic minorities, constant fear of Russia. The economic conditionality has not considered the crisis of the welfare state, and the great sacrifices required to 'enter Europe' have not been rewarded by equal treatment compared to the old member states. This has favored, in many cases, an attitude of jealousy for their sovereignty. For the last aspect, see the remarks by Dimitry Kochenov and Matthijs van Wolferen, "The dialogical Rule of Law and the breakdown of dialogue in the EU”, EUI Working papers, LAW 2018/01, which critize the claim of the Court of Justice to impose in a technical manner values resulting from the constitutional traditions shared by the Member States, which are in fact only the Western ones. New members are not considered to be active bearers of values.

${ }^{75}$ See, e.g., Dmitry Kochenov, EU Enlargement and the Failure of Conditionality in the Fields of Democracy and the Rule of Law (Kluwer Law International, The Hague, 2008). A glaring example of how an instrumental consideration of the rule of law can justify constitutional developments in Poland comes from a long and very well-argued document prepared by a series of constitutional specialists: Report of the Team of Experts on the Issues Related to the Constitutional Tribunal of 15 July 2016, available at <http://www.sejm.gov.pl/media8.nsf/files/ASEAADRKC8/\%24File/Report\%20of\%20the\%20Team\%20of\%20Experts\%20on\%20the\%20Issues\%20Related\%20to\%20t he\%20Constitutional\%20Tribunal.pdf>. The same came be said for the White Paper on the Reform of the Polish Judiciary, published by the Chancellery of the Prime Minister in 2018 available at $<$ https://www.premier.gov.pl/files/files/white_paper_en_full.pdf >. Kalypso Nicolaidis and Rachel Kleinfeld, Rethinking Europe's "Rule of Law" and Enlargement Agenda, SIGMA Papers, no.49, OECD Publishing, Paris, also complain about the excessive technicality of the European parameters and the relative bureaucracy, obsessed by the measurability of the results with respect to the imposed parameters. As the two authors write "the rule of law is distinct from human rights as well as other values, such as democracy, liberty or equality. Elements of these values may be implicit in the rule of law, but lumping them together leads to conceptual confusion and bad practice" (11).

${ }^{76}$ See Bobek op.cit. note 5.

${ }^{77}$ See the special issue of the German Law Journal: 18(7) German Law Journal (2017).

${ }^{78}$ E.g., see Hans W. Micklitz, "Prologue: The Westernisation of the East and the Easternisation of the West", in Bobek 2015, op.cit. note 5 . 
although there is a risk of exploitation of that difference. In fact, in Hungary and Poland the governments have invoked the democratic principle, which they have made coincide with the majority will of the voters, to challenge a legalistic approach to the rule of law. But the rule of law is a 'fluid' notion, as evidenced by the fact that countries which technically respect the (formal) rule of law are not considered to be democratic. ${ }^{79}$ However, despite the constitutional crisis and the limits of democratic conditionality, the transformations made by these countries thanks to the path of European integration are epochal and therefore "it would be mistaken to sign off the CE judicial transformation as a failure". ${ }^{80}$

It is worth expressing some final thoughts on the rule of law and the EU. On the one hand, if not materialized into a concrete rule, the principle of the rule of law is hardly justiciable at the European level, although this is theoretically possible,$^{81}$ as recent evolution of CJEU jurisprudence testifies ${ }^{82}$ On the other hand, the constitutional case law of the new member states indicates that respect for this principle, even considered alone, is still crucial, because they have not overcome the post-communist syndrome, or because they still consider protection of the principles to be relevant for their democratic consolidation.

79 As Dimitry Kochenov and Matthijs van Wolferen, The dialogical Rule of Law and the breakdown of dialogue in the
$E U$, EUI Working papers, LAW 2018/01, 4, argue, considering the doctrinal debate and the guidelines of the Venice
Commission it is more clear what the rule of law is not (it is not democracy or the protection of human rights nor mere
legality) than what it in fact is.
80 Bobek, "Conclusions: Of Form and Substance in Central European Judicial Transitions", in Bobek op.cit. note 5 , 418.
81 With regard to principles such as the rule of law, which are vague and subject to the assessment of national legal
orders, the Court of Justice has always followed a rigid self-restraint. This is evident, e.g., in the decisions on
infringement proceedings against Hungary, where the reasoning was highly technical and did not encourage the
discovery of values, although all the debate around the proceedings was rich in disquisitions of a highly constitutional
level. The Court of Justice's approach to the rule of law at the European level is therefore necessarily different from that
of the national constitutional courts. See von Danwitz, op.cit. note 75 . ${ }^{82}$ We refer to the well known CJEU decision of 27 February 2018 C-64/16 (Associação Sindical dos Juízes Portugueses v. Tribunal de Contas case) in which the Court, referring to general and value-related clauses of EU primary law such as Arts 2 and 19 TEU, particularly emphasized the necessity for member states to respect values such as rule of law (whose essence is 'the very existence of effective judicial review designed to ensure compliance with EU law') and the principle of sincere cooperation. As commentators underlined, this was an occasion for the Court to send a message to the Polish authorities and to anticipate its later decisions on the matter, as was the case in Commission/Poland C-619/18 R (and just before summer 2018 also in Case C-216/18 PPU). In the order of the vice president of the CJEU of 19 October 2018, which forced Poland to adopt interim measures to avoid severe consequences on judicial independence, it is clearly stated that judicial independence is part of the essence of the fundamental right to a fair trial, guaranteeing that the values common to the member states set out in Article 2 TUE, in particular the value of the rule of law, will be safeguarded. For comments see Martina Coli, "The Associação Sindical dos Juízes Portugueses judgment: what role for the Court of Justice in the protection of EU values?", 2018 diritti comparati.it available at <www.diritticomparati.it/associac\%cc\%a7a\%cc\%83o-sindical-dos-juizes-portuguesesjudgment-role-court-justice-protection-eu-values>; Michał Krajewski, "Who is Afraid of the European Council? The Court of Justice's Cautious Approach to the Independence of Domestic Judges", 14 European Constitutional Law Review (2018); Daniel Sarmiento, "Interim Revolutions", VerfBlog, 2018/10/22 available at <verfassungsblog.de/interim-revolutions>; Laurent Pech, Sébastien Platon, "Rule of Law backsliding in the EU: The Court of Justice to the rescue? Some thoughts on the ECJ ruling in Associação Sindical dos Juízes Portugueses", EU Law Analysis, 13 March 2018, available at <http://eulawanalysis.blogspot.com>. 